\title{
Impact of removal pitfall trapping on the community of shrews (Mammalia : Soricidae) in two African tropical forest sites.
}

\author{
V. NICOLAS \\ Laboratoire Ethologie-Evolution-Ecologie, UMR-CNRS 6552, Station Biologique, \\ Université de Rennes 1, 35380 Paimpont, France. \\ P. BARRIERE \\ Laboratoire Ethologie-Evolution-Ecologie, UMR-CNRS 6552, Station Biologique, \\ Université de Rennes 1, 35380 Paimpont, France.
}

M. COLYN Laboratoire Ethologie-Evolution-Ecologie, UMR-CNRS 6552, Station Biologique, Université de Rennes 1, 35380 Paimpont, France. Email : Marc.Colyn@univ-rennes1.fr

KEY WORDS

shrews,

density,

diversity,

removal,

pitfall-trapping,

\section{SUMMARY}

Removal trapping is still used for the study of tropical African shrews biodiversity and ecology, because shrew species identification requires cranio-dental analyses due to the existence of sibling species. Pitfall trapping has been found to be the most effective protocol to collect shrews. However, the impact of removal pitfall-trapping on density and diversity of shrew species is still unknown. In this paper, we test this impact on two African tropical forest shrew communities, by comparing the results of two trapping sessions conducted in two consecutive years. Our results support the view that removal trapping, with conditions described in this paper, does not adversely affect local population numbers and shrew species richness.

\section{RÉSUMÉ}

L'identification de la plupart des espèces de musaraignes tropicales africaines ne peut se faire qu'après analyses crânio-dentaires, en raison de l'existence 
d'espèces jumelles. C'est pourquoi, l'euthanasie de ces micro-mammifères reste nécessaire à l'étude de leur biodiversité et de leur écologie. Le piégeage " pitfall " est reconnu comme la méthode la plus adaptée à la collecte des musaraignes; cependant, l'impact de ce type de piégeage, avec euthanasie des spécimens, sur la densité et la diversité des musaraignes reste méconnu. Nous testons ici cet impact sur deux communautés de musaraignes de forêt tropicale africaine, en comparant les résultats obtenus lors de deux sessions de piégeage effectuées, à la méme place, deux années consécutives. Nos résultats montrent que le piégeage, dans les conditions décrites dans ce papier, n'affecte pas la densité ou la diversité des musaraignes.

\section{INTRODUCTION}

Shrews (Insectivora: Soricidae) constitute a species-rich and ecologically diverse taxon, with 335 described species, which 150 are found in Africa (Wolsan and Hutterer 1998). African lowland tropical forests, an area of high diversity for this group, harbour up to 18 shrew species on a $10.4 \mathrm{Km}^{2}$ forest plot (Barrière and Nicolas 2000). Shrew species are difficult to identify, particularly due to their small size and the existence of sibling species. Thus, identification of most species requires cranio-dental analyses. Similarly, the study of their diets implies stomach contents analyses (Churchfield and Sheftel 1994), thus requiring the killing of the animals. The same is true for epidemiological surveys (Breman et al. 1999 ; Leirs et al. 1999 ; Morvan et al. 1999).

Pitfall-trapping is the most effective protocol to collect shrews (Williams and Braun 1983, Kalko and Handley 1992, Maddock 1992, Kirkland and Sheppard 1994). When used in transect lines with drift fences, this method yields information on the diversity and relative abundance of shrew species (Handley and Kalko 1993). In tropical Africa, this last method has only been used since the middle of the nineties (e.g. Cornélis et al. 1995, Colyn et al. 1996, Stanley et al. 1996). In this part of the world, the ecology (Churchfield 1990, Hutterer 1997, Haberl
2001), life histories (Innes 1994) and social structure (Rychlik 1998) of shrews are still poorly known.

The impact of removal pitfall-trapping on the shrew population density and species richness is still unknown. Therefore, we decided to test this impact on two shrew communities in African tropical forests by comparing the results of two trapping sessions conducted in two consecutive years.

\section{MATERIALS AND METHODS}

\section{Study sites and sampling method}

Sampling was performed in two African lowland rain-forest localities: Batouri, located in the Ngotto forest $\left(03^{\circ} 54 \mathrm{~N}-17^{\circ} 02 \mathrm{E}\right)$, in Central African Republic (C.A.R.), and Moueva, located in Monts Doudou (02 $\left.09 \mathrm{~S}-10^{\circ} 30 \mathrm{E}\right)$, in Gabon. Pitfall lines consisted of 10-litre plastic buckets (26 cm deep, $26 \mathrm{~cm}$ top internal diameter, $20 \mathrm{~cm}$ bottom internal diameter), positioned at $5 \mathrm{~m}$ intervals, along a plastic drift fence bisecting all of the buckets, and extending $2.5 \mathrm{~m}$ beyond the first and last buckets (Fig. 1). The plastic array was inserted into the ground to prevent burrowing through litter beneath the fence, and held 


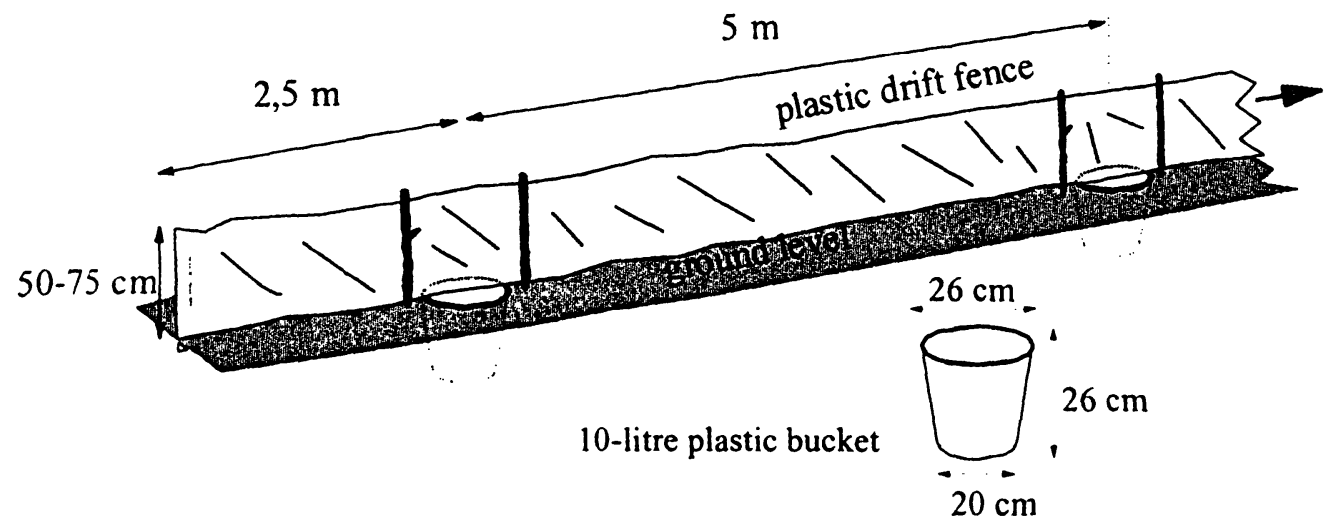

Fig. 1. - Schematic representation of an extremity of the pitfall sampling device used by our team since 1994, with 10-litre plastic buckets and a plastic drift fence, $50-75 \mathrm{~cm}$ high above the ground level.

upright by sticks cut from the forest. Buckets were sunk to a depth where the rim was even with the ground level. Small holes $(3-5 \mathrm{~mm})$ were burned in the bottom of the buckets to allow water drainage. As shown by Table 1 , the number of buckets per line varied from $20(100 \mathrm{~m}$ long line) to $40(200 \mathrm{~m})$. At Batouri, six pitfall lines (B1 to B6), separated at least by $100 \mathrm{~m}$ from each other, were set perpendicularly to the Batouri River, with three lines on either side of the river (more details in Barrière and Nicolas 2000). At Moueva, onc pitfall line (M1) was set in terra firme forest (i.e. forest ground never flooded). All lines were set for 21 days once in one year, and then again once in the following year. At each locality, pitfall lines were set exactly at the same place for the two consecutive years.

Rainfall is known to increase activity of shrews and therefore their trappability (Kirkland and Sheppard 1994), depending on their capacity to enter torpor or not (Churchfield 1990). Therefore, we compared results obtained in seasons with comparable rainfall (July 1999 and 2000 at Batouri; March 2000 and 2001 at Moueva). Daily rainfall was measured during the 21 consecutive days of each trapping session.

\section{Data analysis}

A bucket-night is defined as one bucket in use for a 24-hour period (dawn to dawn), and the trapping effort $(E)$ as the number of bucket- nights. The trap success $(T)$ is defined as the number of shrews caught per 100 bucket-nights ; i.e. $T=(N / E) \times 100$, where $N$ is the number of shrews trapped. We used Chi-square tests $\left(\mathrm{X}^{2}\right)$ for trap success comparisons; a probability of $\mathrm{P} \leq$ 0.05 was considered as significant. The regression coefficient $\left(r^{2}\right)$ of the cumulative number of individuals trapped as a function of time was calculated for each line and each trapping session.

Specific identification was performed at the laboratory by P.B and Rainer Hutterer for the specimens from Batouri, and by P.B. for those from Moueva. The number of species known to occur at Batouri and Moueva is 18 (Barrière and Nicolas 2000) and nine (Nicolas and Barrière 2001) respectively. While all the specimens collected during both trapping sessions at Moueva were identified, those collected during the second trapping session at Batouri could not be identified. Thus, in order to test the impact of removal trapping on the community structure, we only compared the results obtained at Moueva in March 2000 and March 2001. Species relative abundance (pi) is defined as the number of individuals of the species $i$ caught per 100 individuals of all species, i.e. pi $=(n i / N) \times 100$, where $n i$ is the number of shrews of the species $\mathrm{i}$, and $\mathrm{N}$ the total number of shrews. Spearman rank correlation of species abundance between 2000 and 2001 was calculated in order to compare the overall shrew community structure between years.

All statistical analyses were performed by MINITAB 12.2. 


\section{RESULTS}

\section{Rainfall}

At Batouri, the number of rainy days in July 1999 and 2000 were 11 and six respectively, and cumulative rainfalls for the 21 days of survey were 136 and $141 \mathrm{~mm}$. At Moueva, 10 and 13 rainy days occurred in March 2000 and 2001 respectively, with an amount of 101 and $194 \mathrm{~mm}$ of rain.

\section{Trap success}

At Batouri, 142 shrews were collected during the first trapping session, and 154 during the second one; which represents a total trapping success of $4.23 \%$ and $4.58 \%$ respectively (Table
1). These differences, in term of trapping success, are not significant $\left(\chi^{2}=0.360\right.$, d.f. $=1, P=$ $0.549)$. Between the first and the second trapping session, the trap success significantly increased for the line $\mathrm{B} 4$ and decreased for $\mathrm{B} 5\left(\chi^{2}=4.635\right.$, and 5.934 respectively, d.f. $=1, P<0.05$ ), but did not vary significantly for the four other lines $(\mathrm{P}>$ $0.05)$. Whatever the line, and the trapping session, the cumulative number of shrews trapped did not decline as a function of time $\left(0.86<\mathrm{r}^{2}<\right.$ $0.99, P<0.001$ ), as shown in Table 1 . In 1999 , the trap success varied significantly among lines $\left(x^{2}=29.249\right.$, d.f. $\left.=5, P<0.001\right)$, but this difference was only due to the greater number of captures on line B5. Thus, no significant difference was observed when this line was excluded from the analysis $\left(\chi^{2}=5.748\right.$, d.f. $\left.=4, P=0.219\right)$. In 2000 , no significant variation was observed among lines $\left(\chi^{2}=7.635\right.$, d.f. $\left.=5, P=0.718\right)$.

TABLE 1. - Sampling characteristics (number of buckets, sampling period, trapping effort $E$ (in bucket-nights)), number of captures $(N)$ and trap success $(T, \%)$ obtained on the seven pitfall lines. Pitfall lines $B 1$ to $B 6$ were set in Batouri (C.A.R.), and M1 in Moueva (Gabon). $P$ is the probability that trap success differs according to years of trapping ( $P$ associated with Chi-square values) and $r^{2}$ is the regression coefficient of cumulative number of individuals trapped as a function of time.

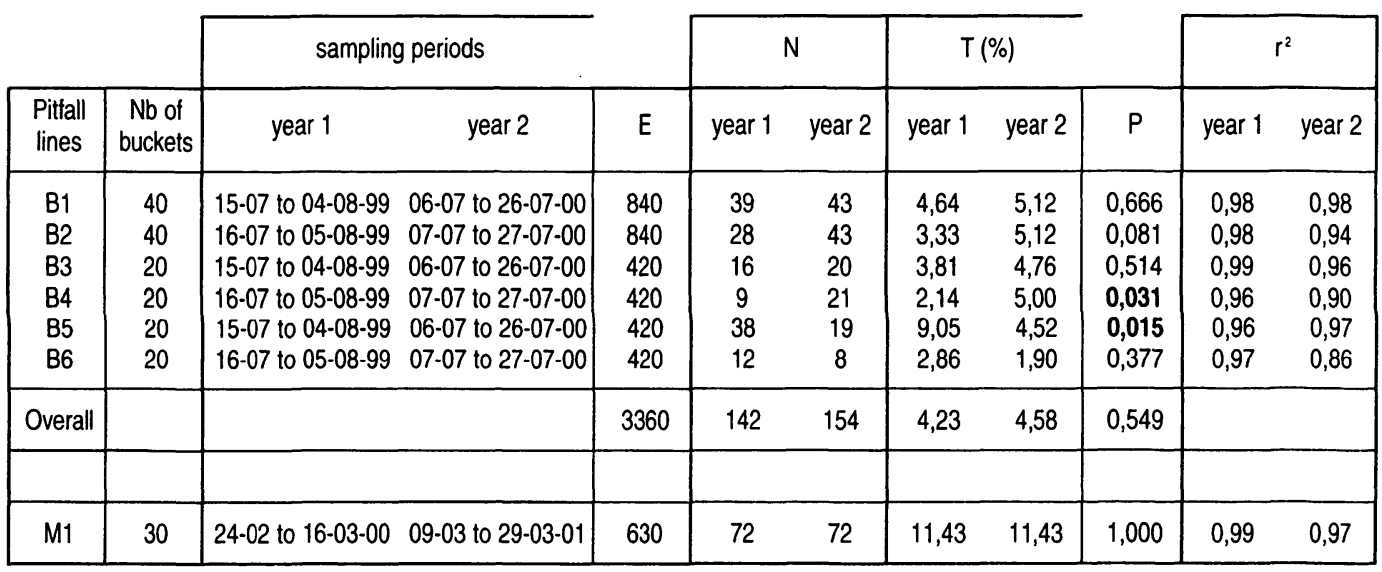

At Moueva, 72 shrews were captured both years, representing a trap success of $11.43 \%$ (Table 1), significantly higher than that of Batouri $\left(\chi^{2}=39.794\right.$ and 46.552 for the first and the second trapping session respectively, d.f. $=1$, $P<0.001)$. Both in March 2000 and March 2001 , the cumulative number of shrews trapped on M1 did not decline as a function of time $\left(r^{2}=\right.$ 0.97 and 0.99 respectively, $\mathrm{P}<0.001$ ).

\section{Species richness and community structure}

At Moueva, seven species out of the nine known to occur were captured in March 2000, after 19 days of trapping (Table 2). In March 2001 , the nine species of the community were caught after 14 days. The two additional species (Crocidura goliath and $C$. grassez) had a low trap success (0.63 and $1.11 \%$ respectively). 
TABLE 2. - Number of individuals of each shrew species captured on line M1 (Gabon) in March 2000 and 2001.

\begin{tabular}{|l|c|c|}
\hline Species & March 2000 & March 2001 \\
\hline Crocidura batesi & 5 & 8 \\
Crocidura crenata & 6 & 8 \\
Crocidura dolichura & 2 & 2 \\
Crocidura goliath & 0 & 4 \\
Crocidura grassei & 0 & 7 \\
Paracrocidura schoutedeni & 21 & 14 \\
Suncus remyi & 2 & 1 \\
Sylvisorex johnstoni & 35 & 23 \\
Sylvisorex ollula & 1 & 5 \\
\hline Total & 72 & 72 \\
\hline
\end{tabular}

There was a significant positive relation between abundance per species in 2000 and $2001(\mathrm{r}=0.70$, $P<0.05$ ), indicating that the overall shrew community structure was similar in both years. Sylvisorex johnstoni was the most abundant species both years $(49 \%$ and $32 \%$ of the total captures in March 2000 and 2001 respectively), Paracrocidura schoutedeni was abundant ( $29 \%$ and $19 \%)$ and the other species were rare $(<10 \%$ each).

\section{DISCUSSION}

At both study sites, the overall trap success did not vary significantly between two trapping sessions, and on six lines out of seven, the trap success did not decrease significantly. In addition, whatever the line and the trapping session, the cumulative number of shrews trapped did not decline as a function of time. At Moueva, the trap success obtained on line $\mathrm{Ml}$ in the second trapping session (11.43\%) was even greater than that obtained on two other neighbouring lines, where no trapping occurred during the first trapping session $(8.57 \%$ and $5.71 \%$, unpublished data). All these results suggest that removal trapping, with conditions described in this paper, does not induce a significant decrease in the density of shrew populations.

Though our data on the impact of removal trapping on community structure are limited to the Moueva study site, our results also support the view that the removal trapping method has no significant effect on species diversity. Indeed, two additional rare species were observed at Brought to you by | Service Bibliotheque
Moueva, on line M1, during the second trapping session, and the species richness obtained on this line (nine species) was higher than on the two neighbouring lines where no previous trapping occurred (six and height species). Then, rare species are known to require an increased trapping effort to be captured. As an example, at Batouri, 41020 bucket-nights were needed to capture the first specimen of Crocidura hildegardeae (Barrière and Nicolas 2000).

Crocidurine populations have a rapid turnover (Churchfield 1990) and the study sites, where trapping were carried out, occupied a minuscule area of an extensive and unfragmented tropical forest. Removal trapping, with such conditions, would not have significant consequence on density and diversity of shrew species, even the rarest ones, and therefore on their conservation.

\section{Acknowledgements}

Field studies were supported by (1) EU-DGVIII Ecofac program "Conservation et Utilisation Rationnelle des Ecosystèmes Forestiers en Afrique centrale ; http ://www.ecofac.org " (managed by AGRECO, GEIE, BDPA, SCETAGRI, SECA, CIRAD-FORET) ; (2) PRGIE-WWF Gabon and (3) EU-DGVIII- Biofac program «Origine et maintien de la biodiversité en Afrique Centrale" (University of Rennes 1 / CNRS, UMR 6552). P. BARRIERE and V. NICOLAS received a fellowship from the Ministère de l'Education Nationale de l'Enseignement Supérieur et de la Recherche (France). We are also particularly grateful to R. HUTTERER (Koenig Museum, Germany) for his precious help in the taxonomy of African Soricidae, A. PENELON (ECOFAC) and $\mathrm{Mm}$ O. LENGRAND, A. KANDEM and P. OBAME ONDO (WWF) for logistic support in the field, and to the local assistants of Ngotto (G. YANGOUNDJARA et R. K. MARO) and Monts Doudou (S. GUIMONDOU). We thank the authorities of the "Ministère des Eaux, Forêts, Chasses et Pêches et du Tourisme" in Bangui (C.A.R.), Mr MANFOUMBI KOMBILA from the "Direction de la Faune et de la Chasse" in Libreville (Gabon) and Mme KOUMBA from the Moukalaba reserve (Gabon). A. GAUTIERHION and P. DELEPORTE provided numerous helpful comments on the manuscript.

\section{BIBLIOGRAPHY}

Barriere, P. and V. Nicolas, 2000. - Rapport d'expertise sur la Biodiversité animale en forêt de Ngotto (République Centrafricaine) : Ecologie et t Documentation IRMAR Universite Rennes 1 
structuration des peuplements de micromammifères: Musaraignes et Rongeurs. Rapport ECOFACCEE, AGRECO-CTFT, 46pp.

(http ://www.ecofac.org/Divers/Telechargement.htm)

Breman J.G., K.M. Johison, G. van Der Groen, C.B. ROBBINS, M.V. SZCZENIOWSKI, K. RUTI, P.A. WeBB, F. MEIER and D. L. HeYMANi, 1999. Ebola Virus Study Teams, A search for Ebola virus in animals in the Democratic Republic of the Congo and Cameroon: Ecologic, Virologic, and Serologic suveys, 1979-1980. J. Infect. Dis., 179 (Suppl 1) : S139-S147.

ChurChfiei.D, S., 1990. - The Natural History of Shrews. Eds. Christopher Helm, London. 175 pp.

Churchfield, S and B.I. Sheftel, 1994. - Food niche overlap and ecological separation in a multispecies community of shrews in the Siberian taiga. J. Zool. Lond., 234 : 105-124.

Colyn, M., D. Cornelis and O. Perpete, 1996. Synthèse "Micro-mammiferes" Muridae et Soricidae, Structure des peuplements : richesse et diversité spécifiques et Indices d'abondance. Rapport ECOFAC-CEE, AGRECO-CTFT, 46pp.

Cornélis, D., M. Colyn, and O. Perpete, 1995. Impact de l'ouverture du couvert sur les peuplements d'insectivores et de rongeurs d'une forêt dense humide au Gabon. Rapport ECOFAC-CEE, AGRECO-CTFT, 96pp.

HaberL, W. 2001. - Insectivore Specialist Group. Species Newsletter of the Species Survival Commission IUCN - The World Conservation Union, $36: 21$.

Handley, C.O., Jr. and E.K.V. KalKo, 1993. - A short history of pitfall trapping in America, with a review of methods currently used for small mammals. Virginia Journal of Science,44 (1) : 19-26.

HUTteri:R, R., 1997. - Insectivore, Trec Shrew, and Elephant Shrew Specialist Group. Species Netusletter of the Species Survival Commission IUCN - The World Conservation Union, $29: 43$.

INNES, D.G.L., 1994. - Life histories of the Soricidae : a review. In : J.F. Merritt, G.L. Kirkland, Jr., and R.K. Rose, eds. Spec. Publ. Carnegie Mus. Nat. Hist. $18: 111-136$.

Kalko E.K.V. and C.O. Handi.eY, Jr., 1992. - Comparative studies of small mammal populations with transects of snap traps and pitfall arravs in southwest Virginia. Virginia J. Sci, $44: 3-18$.

KirkLand, G.L., Jr., and P.K. Sheppari), 1994. - Proposed standard protocol for pitfall sampling of small mammal communities. In : J.F. MERRITT, G.L. KIRKL.AND, Jr., and R.K. ROSE, eds. Spec. Publ. Carnegie Mus. Nat. Hist. $18:$ 277-283.

Leirs H., J.N. Mills, J.W. Krebs, J.E. Chil.ds, D.

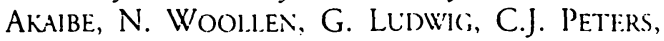
T.G. KSIAZEK and Study group members, 1999. Search for the Ebola virus reservoir in Kikwit, Democratic Republic of the Congo : reflections on a vertebrate collection. J. Infect. Dis., 179 (Suppl 1) : S155-S163.

MADDOCK, A.H., 1992. - Comparison of two methods for trapping rodents and shrews. Israel J. Zool., 38 : 333-340.

Morvan, J., V. Delbei, P. GoliNon, le. Nakoline, P. Barrière, S. Murri, V. Volchiov, O. Perpette, B. SElekoN, D. Colddriter, A. Galtier-HioN and M. Coly's, 1999. - Identification of Ebola virus sequences present as RNA or DNA in organs of different species of terrestrial small mammals of Central African Republic. Micr. Infect., 1(14) : 1193-1201.

NiCOLAS, V. and P. BARRIÈre, 2001. - Diversité biologique du Refuge Forestier Pléistocène des Monts Doudou (Gabon). Rapport IWWF.

Richlik, L., 1998. - Evolution of social systems in shrews. In: Evolution of Shrews. Eds. J.M. Wojcik, and M. Wolsan, Mammal Research Institute, Polish Academy of Science, Bialowieza., p. 347-406.

Stanley, W.T., S.M. Goodman and R. Hütri:Rer, 1996. - Notes on the insectivores and elephant shrews of the Chome Forest, South Pare Mountaines, Tanzania (Mammalia : Insectivora et Macroscelidae). Lool. Abh. Mus. Tierkd. Dresden, 49(8) : 131-147.

WILlianis, D.F and S. BRAUN, 1983. - Comparison of pitfall and conventional traps for sampling small mammal populations. J. Wildlife Manage,. 47 : 841 845.

Wolsan, M. and R. HutTerer, 1998. - Appendix: a list of the living species of shrews, In : Evolution of Shreews. Eds. J.M. Wojcik, and M. Wolsan, Mammal Research Institute, Polish Academy of Science, Bialowieza, 425-448. 